\title{
Bioproduction Phytomelioration of the Salted Soils in Rice Field Systems in the Aral Sea Region of Kazakhstan
}

\author{
Zhanar Shadibekovna Zhumadilova', Ibadulla Aigalievich Tautenov', \\ Karlygash Mamytbekovna Abdieva' ${ }^{1}$, Yerik Zharylkasynovich Shorabaev', \\ Amankeldy Kurbanovich Sadanov ${ }^{1}$ \\ 1 LLP "Research and Production Center of Microbiology and Virology", Bogenbai Batyr Street, 105, Almaty, \\ 050010, Kazakhstan \\ * Corresponding author's e-mail: zhanarzhumadilova@list.ru
}

\begin{abstract}
Rice is the main crop in the irrigated agriculture zone of the Aral Sea region of Kazakhstan. The rice culture is hygrophytic and requires a large amount of irrigation water as well as a washing irrigation regime, which contributes to the leaching of salts from rice paddies. In the rice crop rotation, an active process of salt accumulation in the soil occurs after the rice stage. This happens because of the secondary soil salinization. The aim of the research was to study the salt tolerance and soil desalting properties of the new varieties of melilot during cultivation in the rice crop rotation in the irrigated area of the Aral Sea region of Kazakhstan. The research conducted in the Research and Development Center for the Microbiology and Virology showed that the cultivation of the "Arkas" variety of white melilot and the "Saraichik" variety of dentated melilot on saline soils in the rice crop rotation in the Aral Sea region of Kazakhstan leads to the soil desalination. According to the results of the research, the content of salt solid residue in the arable layer $(0-30 \mathrm{~cm})$ was lower under the "Saraichik" variety of dentated melilot than under the "Arkas" variety of white melilot. The level of groundwater rises and the process of salinization intensifies during the cultivation of crops. The transition from subsaline soils to the soils with a high degree of salinization occurs. The rates of development and growth are slow during the first year in melilot varieties; however, despite the low indicator values, the harvest results in a single mowing were high (229-309 kg/ha of herbage and $57.2-74.3 \mathrm{c} / \mathrm{ha}$ of hay). The "Saraichik" variety has large leaves, branching stems and high foliage. The "Saraichik" dentated melilot has a beneficial feature. This variety is able to use groundwater with high salt content more efficiently for its growth and development. It should be noted that the melilot yield of the first year was harvested in the region without irrigation, and it grew using the moisture reserve accumulated in the soil during the previous year from the watering of the previous culture, i.e. rice. Therefore, the results of the study demonstrated that "Arkas" white melilot and "Saraichik" dentated melilot are promising cultures that can be introduced into the rice crop rotation in the areas with saline soils in rice field systems of the Aral Sea region of Kazakhstan.
\end{abstract}

Keywords: melilot, phytomelioration, salt tolerance, soil fertility, salinity.

\section{INTRODUCTION}

Preservation and maintenance of the floodplain soils fertility in the irrigated areas of the rice field systems of the Aral Sea region of Kazakhstan is very important and requires management as well as optimization of almost all parameters of soil fertility and all properties of arable land soil cover. It is necessary to establish a system for the soil-biological monitoring that will allow controlling the main indicators of soil fertility, soil and plant contamination with residual amounts of chemicals, and development of erosion processes. This will enable to carry out monitoring, forecasting, early intervention and control of soil processes, and assessment of the soil suitability [Saparov, Sharypova 2012].

The agro-ecological conditions of irrigated lands in the rice field systems of the Aral Sea region of Kazakhstan are closely related to the mineralization of collector-drainage water, and wastewater from the rice paddies, which varies 
from 2 to $5 \mathrm{~g} / 1$ and tends to increase. Thus, during the last decade the mineralization of wastewater from the fields increased by $60 \%$. This indicates the ongoing processes of secondary salinization in the area caused by the increased salinity of irrigation and groundwater and insufficient drainage of the area [Tautenov et al. 2003].

The agromelioration surveys of irrigated lands provided with the access to utilities and monitoring of the salt regime of groundwater demonstrated that the saline lands area increases every year. For example, according to the Statistics Agency of the Republic of Kazakhstan, in the Kyzylorda region, the following areas have soils with low to high salinity (out of 277.7 thousand ha of lands provided with access to utilities): nonsaline -353 ha, subsaline -113.6 thousand ha, with medium salinity -108.6 thousand ha, with high and very high salinity -55.1 thousand ha. Chloride-sulfate and sulfate are the most common types of salinity [Tautenov et al. 2003].

One of the ways to improve such secondary saline soils is the cultivation of plants resistant to salinization; this method is actually used as a stage of biological melioration [Tautenov et al. 2015; Nurymov 1998].

The biological methods of melioration of low-yielding soils have various effects on their fertility. The cultivation of phytomelioration cultures that contribute to the solution of basic problems of melioration of low-yielding soils, provides the following effects: removal of the excessive salts in the vegetative mass, replacement of absorbed sodium ions with calcium ions in colloids and humus of these soils, accumulation of new nutrients in the soil, and formation of a solid lumpy-granular structure of the soil [Yurina, Siverinova 2005].

Local adaptation is an important mechanism of plant adaptation to environmental heterogeneity where the salt toxicity leads to strong breeding pressure on the salt tolerance of plants and various ecotypes, noted by several researchers [Li et al. 2017].

Various plants are used as phytomeliorants: trees and shrubs, wild halophytes, as well as cultivated forage plants, which, along with the reclamation of saline soils, provide yields. The use of phytomeliorants that provide the products useful for a human is called bioproduction phytomelioration.
One of thecropsused forbiophytomelioration is melilot. Melilot, as a phytomeliorant, has a desalinization effect on saline soils, accumulates biological nitrogen in the root mass, and possesses high forage value. The substances secreted by the melilot plants roots influence the soil microorganisms and promote their activity as well as accumulation of organic matter, which ultimately contributes to an increase in soil fertility [Sadanov 1993; Abzhalelov 1999; Kanatbaeva 1994; Nurymova 2007].

Including melilot in all crop rotations is a good practice, as it leaves up to $160-200 \mathrm{~kg} / \mathrm{ha}$ of biological nitrogen in the soil for the next culture on the field [Mukhambetov 2009].

In Kazakhstan, large-scale research for the breeding of new salt-tolerant, high-yielding varieties of melilot with good production quality that meet the requirements of modern agriculture and animal husbandry is required.

The aim of our research was to study salt tolerance and soil desalting properties of the new varieties of melilot during cultivation in the rice crop rotation in the irrigated area of the Aral Sea region of Kazakhstan.

\section{MATERIALS AND METHODS}

The "Arkas" variety of white melilot and the "Saraichik" variety of dentated melilot (created (bred) by Dr G.T. Meirman and Dr B. Mukhambetov using the method of biotipical selection) were used as the objects of study. The studies were conducted on the experimental plot of the Karaultyubinsk base station of the Zhakhaev Kazakh Research Institute of Rice. During the field experiment, a rice field was cultivated on the experimental area before melilot (as it usually is in the case of other perennial grass plants). The soil of the experimental plots was meadow-boggy, old-arable typical soil of rice field systems. The humus horizon was rather thin $(0-20 \mathrm{~cm})$ with the humus content of $0.8-1.1 \%$, which indicated low fertility of the soil. A field experiment was carried out in four replicates. The plot area was 50 $\mathrm{m}^{2}$. The placement of experiment variants and replicates on the plots was randomized. The analysis of soil-water extracts was carried out in the Kyzylorda branch of the JSC National Center for Expertise and Certification. 


\section{RESULTS}

In order to achieve our goal, we prepared a research program and the salt regime of the soil of the experimental plot was studied using this program. The soil samples for analysis were taken from the arable horizon of the field experiment plots in the spring before the sowing and in the fall after the harvest. The results of the analysis of the readily soluble salts content in the soil are presented in Table 1.

The data in Table 1 demonstrates that the content of readily soluble salts in the soil of the culture plots changed significantly. In the spring of 2017, before the start of the experiment, the salt dry residue content in the soil was approximately $0.516 \%$, and by the spring of 2018 , this value increased to $1.059-1.125 \%$. The previous culture on the site of the field experiment was rice. This means that during the cultivation of rice, before sowing of the melilot, salts were leached out from the soil, as rice is cultivated in water with washing irrigation regime during the whole vegetative period. The irrigation rates for perennial grasses are much lower compared with rice and do not exceed 2.0-6.0 thousand $\mathrm{m}^{3} / \mathrm{ha}$. This amount of irrigation water is not enough to prevent soil salinization; therefore, the soil salinity increases during the cultivation of upland cultures due to soil overconsolidation, lack of water and upward water flow. By the spring of 2018, salinity reached the values that allowed to classify the soils as highly saline; the salinity types were sulfate and chloride-sulfate. By the end of the second year of melilot cultivation, the degree of soil salinity in the area of its cultivation decreased significantly $(0.542-0.715 \%)$. According to the classification, the soil salinity changed from high to medium. Our data, presented in Table 1, demonstrate that the "Arkas" variety of white melilot and the "Saraichik" variety of dentated melilot have a desalinization effect and can be considered the best phytomeliorants.

During the study, surveys and monitoring of the growth and development of plants of the melilot varieties were carried out, and their productivity indicators were determined under the field conditions. The growth and productivity parameters of melilot are shown in Table 2.

Plant height is one of the indicators characterizing the state of crops and directly affecting the herbage productivity of the perennial grasses. The yields of grasses correlate with their height - the higher the plants, the greater is their tops productivity. The melilot varieties were harvested for herbage and hay during the branching phase, as the vegetative period ends with this phase in the melilot varieties during the first year of growth. Despite the lower plant stand and stem number per area unit, the yield of melilot herbage and hay was high due to high growth. The data in Table 2 demonstrates that the melilot growth was faster during the second year, despite the high salinity of soils. It also produced $229-309 \mathrm{~kg} / \mathrm{ha}$ of herbage per mowing during the first year of growth, and $720-625 \mathrm{~kg} / \mathrm{ha}$ during the second year of growth. During the first year of growth, the herbage yield of the "Arkas" variety was $80 \mathrm{c} /$ ha higher than the yield of the "Saraichik" variety. However, during the second year of growth, the opposite was true - the herbage yield of the "Saraichik" variety was $95 \mathrm{c} /$ ha higher. In total, for two years the herbage yield of the "Saraichik" variety was higher than in the "Arkas" variety by only $1.6 \%$; however, the yield of dry hay was higher by $20 \%$, which indicates that the "Saraichik" variety is superior.

Table 1. Content of water-soluble salts in the soil (in the $0-30 \mathrm{~cm}$ horizon)

\begin{tabular}{|c|c|c|c|c|c|c|c|}
\hline \multirow{3}{*}{ Measure units } & \multirow{3}{*}{ Parameters } & \multicolumn{6}{|c|}{ Parameters, variety plots } \\
\hline & & \multicolumn{3}{|c|}{ "Arkas" white melilot } & \multicolumn{3}{|c|}{ "Saraichik" dentated melilot } \\
\hline & & 2017 , spring & 2018, spring & 2018 , fall & 2017, spring & 2018, spring & 2018 , fall \\
\hline$\%$ & Dry residue & 0.516 & 1.125 & 0.715 & 0.516 & 1.059 & 0.542 \\
\hline \multirow{6}{*}{$\begin{array}{c}\text { mg-eq in } 100 \mathrm{~g} \\
\text { of soil/ } \%\end{array}$} & $\mathrm{HCO}_{3}^{-}$ & $\frac{0.39}{0.024}$ & $\underline{0.039}$ & $\frac{0.15}{0.013}$ & $\frac{0.39}{0.024}$ & $\underline{0.51}$ & $\frac{0.07}{0.009}$ \\
\hline & $\mathrm{SO}_{4}^{2-}$ & $\frac{7.10}{0.341}$ & $\frac{15.3}{0.745}$ & $\frac{10.9}{0.587}$ & $\frac{7.10}{0.341}$ & $\frac{14.9}{0.629}$ & $\frac{10.05}{0.564}$ \\
\hline & $\mathrm{Cl}^{-}$ & $\underline{0.20}$ & $\frac{1.63}{0.144}$ & $\frac{1.1}{0.046}$ & $\underline{0.20}$ & $\frac{1.49}{0.138}$ & $\underline{0.921}$ \\
\hline & $\mathrm{Na}^{+}$ & $\frac{0.87}{0.020}$ & $\frac{1.75}{0.089}$ & $\frac{0.91}{0.073}$ & $\frac{0.87}{0.020}$ & $\frac{1.69}{0.084}$ & $\frac{0.91}{0.071}$ \\
\hline & $\mathrm{Ca}^{2+}$ & $\frac{4.70}{0.094}$ & $\frac{5.21}{0.118}$ & $\frac{3.89}{0.072}$ & $\frac{4.70}{0.094}$ & $\underline{5.64}$ & $\frac{3.91}{0.066}$ \\
\hline & $\mathrm{Mg}^{2+}$ & $\frac{1.97}{0.024}$ & $\frac{2.05}{0.047}$ & $\frac{1.20}{0.030}$ & $\frac{1.97}{0.024}$ & $\frac{2.13}{0.059}$ & $\frac{1.20}{0.030}$ \\
\hline
\end{tabular}


Table 2. Plant height and yield of varieties of clover in the field experiment

\begin{tabular}{|l|c|c|c|c|c|c|}
\hline \multirow{2}{*}{ Varieties } & \multirow{2}{*}{ Years } & \multicolumn{2}{c|}{ Plant height, cm } & \multicolumn{3}{c|}{ Yield of herbage/hay, (c/ha) } \\
\cline { 3 - 6 } & & I mowing & II mowing & I mowing & II mowing & Total \\
\hline \multirow{2}{*}{$\begin{array}{l}\text { "Saraichik" dentated } \\
\text { melilot }\end{array}$} & 2017 & 117 & - & $229 / 57.2$ & - & \multirow{2}{*}{$949 / 229.6$} \\
\cline { 2 - 6 } & 2018 & 236 & - & $720 / 172.4$ & - & \\
\multirow{2}{*}{ "Arkas" white melilot } & 2017 & 126 & - & $309 / 74.3$ & - & \multirow{2}{*}{$934 / 190.4$} \\
\cline { 2 - 6 } & 2018 & 250 & - & $625 / 116.1$ & - & \\
\hline
\end{tabular}

\section{CONCLUSION}

1. The research results demonstrate that melilot varieties have a desalinization effect on the upper layers of the horizon of the soils. After the rice irrigation has been stopped, the soil was being progressively salinized. A transition of soils from subsaline to highly saline occurred. The crops of the "Arkas" variety of white melilot and the "Saraichik" variety of dentated melilot have a desalinization effect on the soils and the salts dry residue content decreased from $1.059-1.125 \%$ to $0.542-0.715 \%$.

2 . The research showed that melilot has the ability to use deep-lying groundwater with a high content of salts for its growth and development.

3. Inclusion of the "Arkas" variety of white melilot and the "Saraichik" variety of dentated melilot into the rice crop rotation extends the haymaking productive period. In addition, due to the technological features of melilot cultivation, and due to the possibility of extension of the sowing period and reduction of the depth and seeding rate, in particular, a multifold decrease in the need for agricultural machinery, fuel, energy, etc. can be achieved.

4. Our studies showed the possibility of reducing the level of soil salinity and improving the condition of the soils using phytomeliorants, i.e. the salt-tolerant crops such as "Arkas" white melilot and "Saraichik" dentated melilot, while also receiving products for a food reserve.

\section{REFERENCES}

1. Abzhalelov A.B. 1999. Biologicheskaya aktivnost lugovo-bolotnykh pochv v zavisimosti ot vneseniya mineralnykh udobrenii i rastitelnykh ostatkov [Biological activity of meadow-boggy soils, depending on the application of mineral fertilizers and plant residues]: avtoref. ... doktora biol. nauk [Author's abstract for the thesis of the Doctor of Biological Sciences]. Almaty, $44 \mathrm{p}$.

2. Kanatbaeva M.A. 1994. Biologicheskaya aktivnost vtorichno-zasolennykh lugovo-bolotnykh pochv pri fitomelioratsii [Biological activity of secondary saline meadow-boggy soils during phytomelioration]: avtoref. ...kandidata biol. nauk [Author's abstract for the $\mathrm{PhD}$ thesis in Biological Sciences]. Almaty, $40 \mathrm{p}$.

3. Li J., Liu H., Yan M., Du L. 2017. No evidence for local adaptation to salt stress in the existing populations of invasive Solidago canadensis in China. PLoS ONE, 12(4), e0175252.

4. Mukhambetov B. 2009. Donnikovye meliorativnye sevooboroty i konveiernoe proizvodstvo kormov na zasolennykh zemlyakh Prikaspiya [Melilot melioration rotations and conveyor feed production on the saline lands of the Caspian Sea region]. Nauchno-agronomicheskii zhurnal, 1(84), 32-35.

5. Nurymov D.E. 1998. Tekhnologiya vyrashchivaniya donnika v usloviyakh maloplodorodnykh pochv Priaralya [The technology of growing melilot on the low-fertility soils in the Aral Sea region]. Vestnik s.-kh. nauki Kazakhstana [Bulletin of agriculture science of Kazakhstan], 1, 31-38.

6. Nurymova R.D. 2007. Tekhnologicheskie priemy vozdelyvaniya donnika $\mathrm{v}$ risovom sevooborote $\mathrm{V}$ usloviyakh Priralya [Technological methods for melilot cultivation in rice crop rotation in the Aral Sea region]: avtoref. ... kandidata $\mathrm{s} / \mathrm{kh}$ nauk [Author's abstract for the PhD thesis in Agricultural Sciences]. Almaty, $26 \mathrm{p}$.

7. Sadanov A.K. 1993. Biologicheskaya aktivnost pochv pod risom v svyazi s optimizatsiei ikh plodorodiya [Biological activity of the soil during rice cultivation in connection with the optimization of their fertility]: avtoref. ... doktora biol. nauk [Author's abstract for the thesis of the Doctor of Biological Sciences]. Tashkent, $42 \mathrm{p}$.

8. Saparov A.S., Sharypova T.M. 2012. Pochvennoekologicheskoe sostoyanie zemel Kyzylordinskoi oblasti i puti ikh ratsionalnogo ispolzovaniya [The Soil-Ecological State of the Lands of the Kyzylorda Region and the Ways of Their Rational Use]. Materialy mezhdunarodnoi nauchno-prakticheskoi konferentsii «Nauchno-innovatsionnye osnovy razvitiya risovodstva $\mathrm{v}$ Kazakhstane i stranakh zarubezhya» [Proceedings of the international scientific-practical conference "Scientific and innovative basis for the development of rice in Kazakhstan and foreign countries"]. Kyzylorda, 30-33. 
9. Tautenov I.A., Nurgaliev N.Sh., Bekzhanov S.Zh. 2015. Osvoenie zasolennykh zemel risovykh sistem putem vozdelyvaniya solustoichivykh kormovykh kultur [Reclamation the saline lands of rice field systems by cultivating sol-resistant forage crops]. Harvard Journal of Fundamental and Applied Studies, "Harvard University Press", 1(7), 164-175.

10. Tautenov I.A., Zhailybai K.N., Baimbetov K.S. 2003. Agroekologicheskie i morfofizio- logicheskie osnovy mineralnogo pitaniya i produktivnosti risa [Agroecological and morphophysiological basis of mineral nutrition and rice productivity]. Almaty, Gylym, 180 p.

11. Yurina L.I., Siverinova I.V. 2005. Vliyanie kulturfitomeliorantov na izmenenie pokazatelei pochvennogo plodorodiya [The effect of phytomeliorants on the change of soil fertility indicators]. Nauchnyi elektronnyi zhurnal KubGAU [Electronic Scientific Journal of KubSAU], 13(05). 